Review

\title{
Arbuscular mycorrhiza and soil nitrogen cycling
}

\author{
Stavros D. Veresoglou ${ }^{\mathrm{a}}$, Baodong Chen ${ }^{\mathrm{b}}$, Matthias C. Rillig ${ }^{\mathrm{a}, *}$ \\ ${ }^{a}$ Freie Universität Berlin - Institut für Biologie, Dahlem Center of Plant Sciences, Plant Ecology, Altensteinstr. 6, D-14195 Berlin, Germany \\ ${ }^{\mathrm{b}}$ Chinese Academy of Sciences, Research Center for Eco-Environmental Sciences, Beijing 100085, China
}

\section{A R T I C L E I N F O}

\section{Article history:}

Received 10 August 2011

Received in revised form 21 November 2011

Accepted 23 November 2011

Available online 5 December 2011

\section{Keywords:}

Arbuscular mycorrhiza

Nitrogen cycle

Denitrification

Nitrification

Leaching

Nitrogen fixation

\begin{abstract}
A B S T R A C T
Nitrogen is a major nutrient that frequently limits primary productivity in terrestrial ecosystems. Therefore, the physiological responses of plants to soil nitrogen $(\mathrm{N})$ availability have been extensively investigated, and the study of the soil $\mathrm{N}$-cycle has become an important component of ecosystem ecology and biogeochemistry. The bulk of the literature in these areas has, however, overlooked the fact that most plants form mycorrhizal associations, and that nutrient uptake is therefore mediated by mycorrhizal fungi. It is well established that ecto- and ericoid mycorrhizas influence $\mathrm{N}$ nutrition of plants, but roles of arbuscular mycorrhizas in $\mathrm{N}$ nutrition are less well established; perhaps even more importantly, current conceptual models ignore possible influences of arbuscular mycorrhizal (AM) fungi on N-cycling processes. We review evidence for the interaction between the AM symbiosis with microbes and processes involved in soil N-cycling. We show that to date investigations have rather poorly addressed such interactions and discuss possible reasons for this. We outline mechanisms that could potentially operate with regards to AM fungal - N-cycling interactions, discuss experimental designs aimed at studying these, and conclude by pointing out priorities for future research.
\end{abstract}

(c) 2011 Elsevier Ltd. All rights reserved.

\section{Introduction}

There are several reasons that justify the extensive attention of the scientific community on the nitrogen $(\mathrm{N})$ cycle. $\mathrm{N}$ is one of the few nutrients in terrestrial ecosystems that may limit growth of both plants (Chapin et al., 2004) and microbial communities (e.g. Demoling et al., 2007) in ecosystems with high carbon availability. Thereby, plants and free-living microbes often compete for available $\mathrm{N}$ pools (e.g. Harrison et al., 2007). As microbes have a competitive advantage for resources, for example because of access to micropores, but on average have a shorter life span, these competitive interactions are complicated and involve both temporal and spatial elements (Bardgett et al., 2005). Additionally, the N-cycle is an almost entirely microbially-driven cycle and plant-microbe interactions may have a dramatic influence on the actual rates of $\mathrm{N}$-cycling (e.g. Craine et al., 2007). Finally, N-limitation of the microbial and especially the plant community is characteristic of ecosystems developing on newly formed soil substrate (Vitousek, 2004; Lambers et al., 2008) and has strong implications to the establishment of vegetation in such areas.

Soil microbial ecology has long remained on the "dark side" of ecosystem ecology, due to a limited ability to study processes at a micro-scale (Tiedje et al., 1999; Wall et al., 2005). Development of

\footnotetext{
* Corresponding author. Tel.: +49 30838 53165; fax: +49 3083853886

E-mail address: matthias.rillig@fu-berlin.de (M.C. Rillig).
}

DNA-based methods provided tools that allowed the study of microbial communities, and represented a critical step in fostering integration of aboveground and belowground ecology (Wardle et al., 2004). The field of soil microbiology has largely focused on descriptive molecular characterization of microbial communities at the scale of single experimental sites (e.g. Mazzola, 2004). More recently, there have been pleas for a more systematic functional analysis of soil microbial processes with an ecosystem perspective (e.g. Rillig, 2004; van der Heijden et al., 2008), together with increasing recognition that ecosystem functioning could be regulated by groups of soil microbes with special functional importance (Harris, 2009), including mycorrhizal fungi (Jansa et al., 2008).

It is well recognized that different mycorrhizal types have varying capacities to access organic and inorganic forms of nutrients in soil (Smith and Read, 2008; Lambers et al., 2008; Read and Perez-Moreno, 2003). Ecto- and ericoid mycorrhizas are characteristic of plants that grow on organic soils, and it is now well established that the activities of the fungi mobilize $\mathrm{N}$ (and probably also $\mathrm{P}$ ) from organic forms thus altering the source of $\mathrm{N}$ accessible to the plant symbionts (e.g. Read and Perez-Moreno, 2003). In contrast, arbuscular mycorrhizas are characteristic of plants growing on mineral soils, where inorganic $\mathrm{N}$ and $\mathrm{P}$ sources are prevalent. Arbuscular mycorrhizas are formed by members of the fungal phylum Glomeromycota (Schüßler et al., 2001). Although only a small fraction of plant species have actually been examined, it is believed that the majority of plant species are potentially capable of forming arbuscular mycorrhizas (e.g. Wang and 
Qui, 2006). This symbiosis is inarguably the most common and widespread root symbiosis, and we limit our discussion in this paper largely to this type of mycorrhiza. AM fungi are obligate symbionts and obtain all their organic carbon $(C)$ requirements from their plant partners. In consequence their activities are not limited by organic $\mathrm{C}$ substrates in soil, as is the case for many free-living microbes including those involved in nutrient cycling. The symbiosis is often mutualistic based largely on exchange of $C$ from the plant and $P$ delivered by the fungi (Smith and Smith, 2011). Other benefits include tolerance of pathogens and improved water relations (Newsham et al., 1995; Sikes et al., 2010). AM fungi may therefore modulate ecosystem resilience to abiotic (e.g. nutrient deficiency, water stress, temperature stress - Garrido et al., 2010; Bunn et al., 2009) and biotic stresses (e.g. plant pathogens, herbivory - Koricheva et al., 2009; Shah et al., 2008) and could thus be important ecosystem drivers. AM associations are characteristic of plant species of an intermediate successional stage when the amount of $\mathrm{N}$ that has been immobilized in the organic litter layer is small (Smith and Read, 2008) and tropical biomes.

Within the manuscript our discussion addresses different hierarchical scales in the ecosystem but mainly focuses on the rhizosphere, the zone around the root that is directly influenced by rhizodeposition as well as by depletion or accumulation of nutrients (Uren, 2000). A hypothetical exclusion of AM fungi would cause massive changes to the rhizosphere; the term mycorrhizosphere may be more appropriate to describe the area that surrounds the root system in the mycorrhizal state (e.g. Andrade et al., 1998); to describe the analogous region surrounding individual AM fungal hyphae, the term hyphosphere has been used. Initially we discuss five potential pathways via which AM-induced effects on $\mathrm{N}$-cycling may operate, arrayed from smallest spatio-temporal scale to largest (Fig. 1). We then analyze mechanisms relevant to main $\mathrm{N}$-cycling processes. We conclude with potential solutions to experimental issues and make suggestions for prioritizing future research.

\section{Potential pathways of AM-mediated effects on the N-cycle}

\subsection{Substrate availability}

An obvious pathway via which the AM status of plants could exert an influence on $\mathrm{N}$-cycling processes is via substrate availability in soil (Fig. 1). With the exception of nitrogen fixation, where high concentrations of $\mathrm{N}_{2}$ are present in the soil air (Enoch and Dasberg, 1971), all other $\mathrm{N}$-cycling transformation rates may be regulated by substrate availability. AM fungi may reduce availability of substrates for free-living $\mathrm{N}$-cycling microbiota through immobilization of inorganic $\mathrm{N}$ into their mycelium or transfer of nutrients to their host. For example, they may reduce ammonium $\left(\mathrm{NH}_{4}^{+}\right)$ levels in the soil (e.g. Johansen et al., 1992), and thus introduce a potential limitation for nitrification, or mediate nitrate $\left(\mathrm{NO}_{3}^{-}\right)$ uptake (e.g. Govindarajulu et al., 2005; Fig. 1) and thus potentially limit denitrification and $\mathrm{N}$ leaching. Moreover, turnover of AM extraradical hyphae (Olsson and Johnson, 2005) and AM hyphal exudation (Hooker et al., 2007; Toljander et al., 2007) could enrich soil beyond the zone of direct root influence with carbon and lift carbon limitation for several groups of heterotrophic microbes involved in the $\mathrm{N}$-cycle. Finally, mobility and availability of $\mathrm{N}$-compounds is known to be regulated by several abiotic factors such as pH (Marschner, 1995), as discussed in the next section.

\subsection{Modification of the abiotic soil environment}

There have been a number of reviews on AM-mediated effects on soil aggregation showing improvement of soil aggregation in the mycorrhizosphere (e.g. Tisdall and Oades, 1982; Miller and Jastrow,



Fig. 1. Diagram of the five proposed general pathways via which arbuscular mycorrhizal fungi could cause changes in $\mathrm{N}$-cycling processes. These include, as highlighted by the numbered bullet points, (1) substrate availability; (2) modification of the abiotic soil environment; (3) microbial community shifts; (4) individual host plant level effects; and (5) plant community shifts. For more information on the proposed pathways the reader is directed to text Sections $2.1-2.5$, respectively. For the example of denitrification -for more details please consult Section 3.4, (1) could correspond to $\mathrm{NO}_{3}^{-}$availability; (2) could be the influence of improved aeration through macroaggregate formation; (3) could be hyphal exudation and the resulting shifts in hyphosphere microbial communities; (4) would refer to proximity of denitrifiers to plant roots as more denitrifiers may benefit from exudation of a larger host plant; and (5) signifies the effects of plant identity and/or plant community composition.

2002; Rillig and Mummey, 2006). Modification of soil aggregation (Fig. 1) affects aeration of soil, and this could have an impact on nitrification and denitrification, the two $\mathrm{N}$-cycling processes that are affected by oxygen concentration in the soil air. Moreover, AM presence could affect soil $\mathrm{pH}$, as suggested by a limited number of studies (e.g. Li et al., 1991; Bago et al., 1996; Marschner and Baumann, 2003), and consequently modify availability of $\mathrm{N}$-compounds (for example pH below 5.5 is detrimental for nitrification (e.g. De Boer and Kowalchuk, 2001) and this may reduce availability of $\mathrm{NO}_{3}^{-}$). Modification of carbon content of the soil could mediate changes in soil properties such as water holding capacity (e.g. Bouyoucos, 1939) and thus influence moisture-sensitive N-cycling processes such as nitrification (e.g. Avrahami and Bohannan, 2007), denitrification (e.g. Davidson et al., 1993) and leaching (e.g. Currie and Aber, 1997).

\subsection{Microbial community shifts}

Changes in resources (substrates) and abiotic conditions as well as generation of specialized niches in the hyphosphere and potential allelopathic interactions (i.e. interference competition) could result in AM-mediated shifts in microbial communities (e.g. Marschner et al., 2001). Increasing evidence over the last few years reveals that AM fungi have the ability to modify the microbial community in the rhizosphere (e.g. Marschner et al., 2001; Rillig 
et al., 2006a; Singh et al., 2008) and hyphosphere (e.g. Toljander et al., 2006). Specific groups of microbes such as bacteria of the genus Azospirillum and some species of Pseudomonas (e.g. Walley and Germida, 1997; Vázquez et al., 2000; Fig. 1) have been reported to be favored whereas others decline (e.g. Burkholderia capacia - Albertsen et al., 2006). N-cycling processes could be affected directly, through modification of densities of microbes directly related to $\mathrm{N}$-cycling processes such as Azospirillum spp. (e.g. Vázquez et al., 2000) or indirectly through shifts in the intensity of competition for exudates (e.g. Christensen and Jakobsen, 1993) and rhizoplane colonization (Fitter, 2005) with non-N-cycling heterotrophic microbes. Direct allelochemical suppression of microbes by AM fungal hyphae is also a theoretical possibility, although no evidence for this exists.

\subsection{Individual host plant level effects}

The outcome of colonization of plants with AM fungi is commonly an increase in their size (Lekberg and Koide, 2005; Hoeksema et al., 2010). Although some experimental procedures such as sterilization may have contributed to these observed effects on plant growth (e.g. Brinkman et al., 2010; Hoeksema et al., 2010), we have no reason to believe that AM fungi do not induce an increase in plant size that could include also a bigger root system (for a quantitative analysis of root/shoot ratio responses see Veresoglou et al., 2011a). Spatial extension of the rhizosphere, a well known "hot spot" of microbial activity (Nannipieri et al., 2003), means that N-cycling processes may thus occur in a larger soil volume (Fig. 1). Despite the high overlap of plant roots in the surface soil, root exploitation of soils becomes less intense deeper in the soil profile (e.g. Jackson et al., 1996), and an AM-induced increase in root size at these depths could stimulate $\mathrm{N}$-cycling processes.

\subsection{Plant community level shifts}

The AM fungal community can induce plant community shifts (e.g. van der Heijden et al., 1998; Landis et al., 2005; Wolfe et al., 2006). This raises the question whether these shifts could lead to changes in N-cycling processes (Fig. 1). Plant species identity is a well known regulator of $\mathrm{N}$-cycling rates in the rhizosphere (e.g. Olsson and Falgengren-Grerup, 2000; Van der Krift and Berendse, 2001; Veresoglou et al., 2011b) and thus AM fungusinduced changes in plant community compositional should impact the $\mathrm{N}$-cycle.

An example of a case of AM-induced plant community shifts is the shift from $C_{3}$ grass dominance to $C_{4}$ grasses. Studies on AM species dependency, the weighted difference in dry weight biomass of a plant in the presence and absence of mycorrhizas, have revealed that $\mathrm{C}_{4}$ grasses are considerably more responsive to AM fungi than $C_{3}$ grasses (Wilson and Harnett, 1997, 1998). Additionally, Collins and Foster (2009) were able to establish AM-free and AM-inoculated mesocosms of adequate size to address community shifts in abundance of grasses. Their targeted experimentation revealed a decline in abundance of $\mathrm{C}_{4}$ grasses in the AM-free mesocosms with a concomitant increase of $C_{3}$ grasses (Collins and Foster, 2009). This shift may be one example of a more generalized change toward plants that respond positively in terms of growth. Interestingly, plant litter from $\mathrm{C}_{4}$ grasses typically is of inferior quality (less decomposable) of that from $C_{3}$ grasses (e.g. Dijkstra et al., 2006). Litter quality is known to be a key trait that affects N-mineralization (Van der Krift and Berendse, 2001) and consequently other $\mathrm{N}$-cycling processes such as nitrification (Booth et al., 2005).

\section{AM-mediated effects on individual $\mathrm{N}$-cycling processes}

\section{1. $N$-uptake and $N$-mineralization}

\subsubsection{Available evidence for AM fungal involvement}

AM fungi assimilate $\mathrm{N}$ either exclusively (Tanaka and Yano, 2006) or predominantly (Govindarajulu et al., 2005) in the form of $\mathrm{NH}_{4}^{+}$. Moreover, evidence accumulates that AM fungi may possess the ability to mobilize N from organic sources (Hodge et al., 2001, 2010; Atul-Nayyar et al., 2009; Leigh et al., 2009; Hodge and Fitter, 2010; Barrett et al., 2011). Abovementioned studies have revealed that the $\mathrm{N}$ mobilized from patches can account for up to $32 \%$ of the total $\mathrm{N}$ present in the patch (Leigh et al., 2009), that $\mathrm{N}$ mobilization is possible at temperatures close to $10{ }^{\circ} \mathrm{C}$ (Barrett et al., 2011) and that $\mathrm{N}$ mobilization may take place even when an AM fungus fails to stimulate plant growth (Hodge and Fitter, 2010). It is striking, however, that the vast majority of studies that addressed the ability of AM fungi to facilitate $\mathrm{N}$ acquisition have targeted AM fungal isolates in the Glomeraceae. By contrast two studies that included isolates from the Gigasporaceae detected an inferior ability of these isolates to contribute to plant N nutrition (Reynolds et al., 2005; Veresoglou et al., 2011c). The $\mathrm{N}$ requirements of the AM fungus are known to be high (Hodge and Fitter, 2010) and this may complicate the interpretation of pot experiments.

Notwithstanding the consensus that AM fungi are able to transfer $\mathrm{N}$ to the host plant, the ecological importance of such $\mathrm{N}$ transfer via the AM pathway remains controversial, for several reasons. Experiments often reveal little or no increase in plant $\mathrm{N}$ content (reviewed by Leigh et al., 2011; but see Atul-Nayyar et al., 2009; Veresoglou et al., 2011c; Smith and Smith, 2011). Smith and Smith (2011) have criticized the large size of the hyphosphere compartments in microcosm experiments commonly used to assess $\mathrm{N}$ transport, which would lead to biased estimates of amounts transferred. Additionally, experimental designs to date also did not adequately control for mass flow and diffusion. Another criticism of experimental work has been that many studies neglected to introduce a bacterial/microbial community (Frank and Groffman, 2009). This could have either led to an overestimation of the ability of AM fungi to translocate labeled $\mathrm{N}$ from hyphosphere compartments (Leigh et al., 2011) but, also, may have allowed non-mycorrhizal plants in non-compartmented microcosms to more efficiently assimilate exchangeable $\mathrm{N}$ since competition with the microbial community was suppressed. Thus, the quantitative contribution of the AM pathway remains unclear as far as physiological data are concerned. Reynolds et al. (2005) suggested that the ecological significance of $\mathrm{N}$ transfer might be greatest when $\mathrm{N}$ availability is low, but as argued by Fitter et al. (2011) not much data are available in support of this notion. We suggest that the ecological significance of AM fungi may also be in the exploitation of pulses in $\mathrm{NH}_{4}^{+}$availability in the soil environment. The idea is in agreement with Fitter et al. (2011) that proposed that AM fungi might be able to contribute to plant $\mathrm{N}$ nutrition under conditions of high $\mathrm{N}$ availability. Root proliferation in $\mathrm{NH}_{4}^{+}$-rich, ephemeral patches may be costly for the host plant but much more cost-effective for the high-turnover fraction of the AM fungal mycelium (Staddon et al., 2003). Improved ability of the AM fungi - compared to plant roots - to assimilate $\mathrm{NH}_{4}^{+}$(as revealed from their ability to more effectively deplete $\mathrm{NH}_{4}^{+}$in the soil environment e.g. Johansen et al., 1992) might allow them to better compete with soil microbes and assimilate adequate $\mathrm{N}$ first for their needs, but also in the case of $\mathrm{N}$ pulses, for transferring $\mathrm{N}$ to their plant hosts.

With regards to claims on accelerated decomposition in the AM mycorrhizosphere (e.g. Hodge et al., 2001) we note that superior ability to mobilize organic $N$ from patches does not necessarily imply accelerated mineralization of the patch because in non-mycorrhizal 
systems much of the net mineralized $\mathrm{N}$ might have been immobilized by the surrounding microbial community. The literature, so far with the sole exception of the work of Hodge et al. (2001) where decomposition was assessed indirectly through isotope labeling, has addressed plant nutritional aspects of $\mathrm{N}$-decomposition and this is reflected in the absence of a single study that actually assesses $\mathrm{N}$-mineralization or ammonification in the presence/absence of AM fungi. Hodge et al. (2001) have been able to demonstrate that AM colonized labeled carbon patches were more depleted in ${ }^{13} \mathrm{C}$ but this could as well be attributed to factors not related with decomposition. Such factors include hyphal exudation of unlabeled C (Hooker et al., 2007) that was then incorporated in microbial biomass or higher microbial activity in the presence of the AM fungus that would have modified the amount of labeled ${ }^{13} \mathrm{C}$ that was respired. Thereby, we believe that more targeted experimentation is required with regards to the fate of the patch following AM colonization, as well as the ability of the surrounding community to assimilate the label in the presence and absence of AM fungal extraradical hyphae.

\subsubsection{Mechanisms of AM fungal involvement}

Identification of AM fungal genes related to primary $\mathrm{N}$ nutrition such as glutamine synthetases and some nitrate reductases (Govindarajulu et al., 2005; Tian et al., 2010) suggested that extraradical hyphae of AM fungi have the ability to assimilate $\mathrm{N}$ in the forms of $\mathrm{NH}_{4}^{+}$and, possibly $\mathrm{NO}_{3}^{-}$. The ability of AM colonized plants to more effectively deplete inorganic $\mathrm{N}$ from soil (e.g. Johansen et al., 1992 ) could be attributed either to their more thorough colonization of the soil environment or to an improved ability to assimilate inorganic $\mathrm{N}$ through efficient high-affinity $\mathrm{NH}_{4}^{+}$and $\mathrm{NO}_{3}^{-}$transporters. Alternatively, exudation of sugars from the AM fungal hyphae could intensify microbial competition in the hyphosphere and consequently immobilization. An improved ability of AM fungi to explore the soil environment could explain why AM fungi preferentially assimilate immobile $\mathrm{NH}_{4}^{+}$and not the highly diffusible $\mathrm{NO}_{3}^{-}$. Other reasons that may be used to explain this observation include the absence of benefits for the plant from acquiring $\mathrm{NO}_{3}^{-}$via the mycorrhizal pathway (Fitter et al., 2011) or the higher assimilation cost of $\mathrm{NO}_{3}^{-}$compared to $\mathrm{NH}_{4}^{+}$(e.g. Raven et al., 1992) that could render the supply of the host plant with $\mathrm{NO}_{3}^{-}$derived $\mathrm{N}$ inexpedient. However, much of the evidence on AM-mediated $\mathrm{N}$ uptake has been obtained in controlled experiments where the soil environment of the microcosms is extensively colonized by plant roots and AM fungal hyphae (e.g. Johansen et al., 1992 - as reviewed by Smith and Read, 2008) and in the absence of a representative soil bacterial community (Frank and Groffman, 2009); under these conditions an improved physiological capacity of AM fungi to lower inorganic $\mathrm{N}$ levels is more plausible.

Less is known about the pathway through which AM-assimilated $\mathrm{N}$ could be transferred to the host plant and the extent of such a transfer (Jin et al., 2005; Tian et al., 2010; Smith and Smith, 2011). High concentrations of $\mathrm{NH}_{4}^{+}$may become toxic to living organisms (Temple et al., 1998) and transformation of $\mathrm{N}$ to a less toxic form is required. There is evidence that this organic compound may be arginine (Arg) (Jin et al., 2005; Tian et al., 2010). The fate of the organic skeleton of Arg following $\mathrm{N}$ transfer, whether the AM fungus is able to recapture the carbon and how, remains an issue (reviewed in Smith and Smith, 2011). Also, it is not known, as noted by Fitter et al. (2011), if mycorrhizal plants (compared to non-mycorrhizal plants) are able to down-regulate plant $\mathrm{N}$ - transporters in a way similar to P transporters (Bucher, 2007; Javot et al., 2007). Moreover, it is not yet clear why AM fungi should engage in the costly process of transferring $\mathrm{N}$ to their host plants, unless direct benefits exist. Helgason and Fitter (2009) proposed a model according to which AM fungal supplied phosphate through an increase of background levels of hexoses in the apoplast allows the AM fungus to better scavenge for carbohydrates - a model that has been supported by the experimental results of Kiers et al. (2011); this mechanism, that assimilated nutrients may be "exchanged" by the AM fungi for carbohydrates in the apoplast, could be generalized for the case of $\mathrm{NH}_{4}^{+}$.

There appears to be no evidence that AM fungi contribute to $\mathrm{N}$-mineralization directly through secretion of $\mathrm{N}$-mineralization enzymes. However, they may exert indirect effects through modifying the microbial community so that the degradation ability of organic matter is enhanced (e.g. Griffiths et al., 2001; Liebich et al., 2007). Evidence is accumulating that AM fungi initiate a modification of the microbial community in the hyphosphere/(mycor) rhizosphere (e.g. Rillig et al., 2006a; Toljander et al., 2006) and there could potentially be indirect ways through which $\mathrm{N}$-mineralization and uptake is affected. A typical example with regards to P nutrition is growth of phosphate solubilizing bacteria that appears to be promoted in the presence of AM fungi (Toro et al., 1997), which should in turn lead to improved $\mathrm{P}$ economy of the host plant. According to the N-mining hypothesis (Moorhead and Sinsabaugh, 2006; Craine et al., 2007) accelerated decomposition is predicted when availability of $\mathrm{N}$ declines; AM fungi are believed to intensify bacterial competition for inorganic $\mathrm{N}$ sources (e.g. Johansen et al., 1992) and this could facilitate decomposition. However, the contribution of bacteria to the decomposition of complex substrates is believed to be more limited than that of fungi (e.g. de Boer et al., 2005) and possibly any modification of the bacterial community following AM colonization would be of minor importance.

\section{2. $N_{2}$-fixation}

\subsubsection{Evidence for AM fungal involvement}

$\mathrm{N}_{2}$-fixation represents the single most studied $\mathrm{N}$-cycling process with respect to the impact of AM colonization. Puppi et al. (1994) hypothesized that AM colonization could alleviate the high $\mathrm{P}$ requirements of the nitrogenase enzymes and, thus, result in an increase of plant-host growth. Indeed, co-inoculation of legumes with AM fungi results in increases in their N-fixing ability (e.g. Smith and Daft, 1977; Abbott and Robson, 1978; Abbott et al., 1979; Ibijbijen et al.,1996; Toro et al., 1998). Moreover positive effects on Frankia (Jha et al., 1993; Yamanaka et al., 2005; Oliveira et al., 2005), Azotobacter (Sharma et al., 2002) and Azospirillum (Vázquez et al., 2000; Volpin and Kapulnik, 1994) $\mathrm{N}_{2}$-fixing ability or abundance have been recorded in several studies. However the interactive effects of AM fungi and $\mathrm{N}_{2}$-fixing organisms are not necessarily positive for planthost growth. Larimer et al. (2010) and Kaschuk et al. (2010) conducted meta-analyses on the available literature and noted an absence of further plant-host responses when plants were simultaneously colonized with AM fungi and either rhizobia or free-living $\mathrm{N}_{2}$-fixers, despite the fact that responses to separate inoculation with either AM fungi or $\mathrm{N}_{2}$-fixers were positive. With regards to qualitative shifts in the nitrogen fixers-community, Welsch et al. (2010) manipulated the AM community through the addition of benomyl in the rhizosphere of Spartina patens and recorded nifH gene community differences that were maximized at the vegetative point of $S$. patens growth. In the absence of sequencing, though, it could not be evaluated which specific nitrogen fixers were favored through the suppression of mycorrhizas.

AM fungi have been found to colonize non- $\mathrm{N}_{2}$-fixing legume nodules only rarely (Scheublin and van der Heijden, 2006). A potential reason of inhibition of $\mathrm{N}_{2}$-fixation in the nodules in the study of Scheublin and van der Heijden could have been AM colonization (Scheublin and van der Heijden, 2006). Garg and Manchanda (2008), however, were able to demonstrate that Glomus mosseae possesses the ability to moderate premature nodule senescence. Analysis of the fungal communities of the AM colonized nodules 
revealed differences from those that supported an active rhizobial community (Scheublin et al., 2004). Additional $\mathrm{N}_{2}$-fixation may occur in the AM extraradical hyphae as AM extraradical hyphae appear to possess the potential ability to fix atmospheric $\mathrm{N}_{2}$ through harboring intracellular bacteria of the genus Burkholderia (Bianciotto et al., 1996; Minerdi et al., 2001). However, the ecological significance of this $\mathrm{N}_{2}$-fixing mechanism needs to be determined (Kneip et al., 2007), and the existence of a gene or even the expression of it does not necessarily imply a physiological effect.

\subsubsection{Mechanisms of AM fungal involvement}

Nitrogen fixers represent a heterogeneous group of organisms with large ecological niche differentiation among species. Some occur at comparable densities in rhizosphere and "bulk" soil such as the genera Azotobacter and Azoarcus; others, such as the genera Herbaspirillum and Azospirillum represent typical rhizosphere colonizers (Mrkovački and Milić, 2001; Bashan et al., 2004), whereas rhizobia possess the ability to infect roots and elicit formation of root nodules (Stacey, 2007). Much of the available literature on nitrogen fixation focuses on the rhizobium-legume symbiosis because of its high impact on ecosystem primary productivity (Rengel, 2002). The ability of legumes to partition root carbon amongst the two groups of symbionts, rhizobium and AM fungi, has been insufficiently addressed (a single study is available by Paul and Kucey, 1981), and the two groups of microorganisms may represent competing carbon sinks. The high P requirements of nitrogenase (Puppi et al., 1994), however, could mask any competitive interactions and allow an increase in the $\mathrm{N}$-fixing ability of Rhizobia following association with AM fungi as a result of improved P nutrition.

On the other hand, extension of P depletion zones in the mycorrhizosphere could be detrimental to the $\mathrm{N}$-fixing ability of associative $\mathrm{N}$-fixers. Interactions of AM fungi with non-symbiotic N-fixers would be based on different mechanisms, and these are likely weaker. A potential relationship may be stronger for typical rhizosphere colonizers such as Herbaspirillum and Azospirillum as they are more dependent on plant derived carbon. Qualitative modification of exudates following AM colonization is believed to involve a decline in total sugars and an increase in release of $\mathrm{N}$-rich compounds (Jones et al., 2004). Both changes could intensify carbon limitation of rhizosphere microbes and diminish the potential advantage of $\mathrm{N}$-fixers over other microbes. Thus, a decline in the performance of $\mathrm{N}$-fixers could be expected. However, many of the rhizosphere colonizers are versatile organisms. Azospirillum spp., the most studied non-symbiotic $\mathrm{N}$-fixers, exhibit extensive phenotypic adaptation to conditions of carbon and $\mathrm{N}$ - limitation (Blaha and Schrank, 2003). As a result, the non-symbiotic N-fixing microbial community may not be very responsive to AM-induced changes.

\subsection{Nitrification}

\subsubsection{Evidence for AM fungal involvement}

Available literature for impacts of AM on nitrification is limited to three studies. Amora-Lazcano et al. (1998) observed that inoculation of maize with G. mosseae and Glomus fasciculatum facilitated establishment of culturable ammonia oxidizing bacteria in the soil. However, in this study, sequential harvesting of the microcosms revealed that the $\mathrm{AO}$ community had not reached equilibrium till the final harvest. By contrast, Cavagnaro et al. (2007) failed to detect differences between mycorrhiza defective mutant tomatoes and their wild-type progenitors in either the composition (assessed through denaturing gradient gel electrophoresis -DGGE- fingerprinting) or the density (assessed through real-time polymerase chain reaction -PCR) of ammonia oxidizing bacteria. The authors noted that this could have been due to the short ( 2 months) duration of the experiment (Cavagnaro et al., 2007). By contrast, Veresoglou et al. (2011b) were able to demonstrate in a series of four experiments that nitrification potential rates (an indirect measure of the size of the AO community) of mycotrophic plants were consistently lower than those of non-mycorrhizal representatives. Thus, in three different studies the full range of potential results of AM on nitrification or nitrifying organisms has been obtained: increase, no change, and decrease. While the studies are not directly comparable, there is a clear need for systematic study of this $\mathrm{N}$ transformation process.

\subsubsection{Mechanisms of AM fungal involvement}

As autotrophic organisms, ammonia oxidizers (AO) are not directly affected by AM-colonization related changes in rhizodeposition or carbon-substrate related hyphosphere effects, at least compared to the direct effects on heterotrophic soil microbiota. Nevertheless, there could still be indirect effects, via physio-chemical changes mediated by AM fungi. With regards to interspecific competition for nutrients other than $\mathrm{C}$ and $\mathrm{N}$, dependence of the competing microbial community on plant derived $\mathrm{C}$ could generate favorable conditions for ammonia oxidizer proliferation in the mycorrhizosphere through the decline in sugar exudation that follows AM colonization (Jones et al., 2004). However, a suppression of the competing microbial community could, also, be detrimental if $\mathrm{N}$-mineralization rates are affected and $\mathrm{NH}_{4}^{+}$-substrate availability declines. The "priming effect" describes the disproportionate increase in $\mathrm{N}$-mineralization that may be induced following the addition of very small amounts of carbon (de Nobili et al., 2001; Ma et al., 1999). In a similar way, the decline of carbon availability that occurs in the mycorrhizosphere could possibly result in a decline in ammonification that would induce substrate limitation in ammonia oxidizers.

Ammonia oxidizers are weak competitors for soil exchangeable $\mathrm{NH}_{4}^{+}$(Bollmann et al., 2002) and, thus, under $\mathrm{N}$ limiting conditions, sensitive to the presence of other $\mathrm{NH}_{4}^{+}$-depleting organisms such as AM fungi. A potential explanation of decreased nitrification rates in the mycorrhizosphere (e.g. Veresoglou et al., 2011b) could thus be competition for $\mathrm{NH}_{4}^{+}$. If it is a selective advantage for AM fungi to deliver $\mathrm{NH}_{4}^{+}$(rather than $\mathrm{NO}_{3}^{-}$) to their hosts to receive carbon in exchange, AM fungi may also possess the ability to suppress ammonia oxidizers via interference competition, i.e. with allelochemicals.

A final mechanism could be an indirect AM-mediated effect on nitrification through altered root structure. AM fungi can cause increases in lateral root length, branching and fine root length (Hooker et al., 1992; Yao et al., 2009). Since fine roots decompose much faster (e.g. Gill and Jackson, 2000), a more elaborate system may permit accelerated root $\mathrm{N}$-mineralization and, thereby, favor nitrification rates (Booth et al., 2005). Simultaneously, a more elaborate root system may allow the plant to more effectively compete for nutrients (e.g. Fitter et al., 1991). In both scenarios the outcome of the altered root structure is an acceleration of $\mathrm{N}$-cycling.

\subsection{Denitrification}

\subsubsection{Evidence for AM fungal involvement}

There has been one study of the interactive effect of AM fungi on the denitrifying community. Amora-Lazcano et al. (1998) were able to demonstrate a decrease in counts of denitrifying bacteria in the presence of AM fungi. However, their harvesting technique (coring) could have affected carbon availability in the microcosms through severing roots, thus impacting denitrification rates. Some additional evidence is available on the interactive effect of AM fungi and some verified denitrifying strains of Pseudomonas such as Pseudomonas putida (evidence from Kim et al., 2008) and Pseudomonas fluorescens (evidence from Samuelsson et al., 1998), even though it is unclear to what degree these results can be generalized to 
denitrifying microbes at large. In most instances, results on modified bacterial abundance may provide little information of changes in the rates of the respective $\mathrm{N}$-cycling processes as bacteria are well known to possess a remarkable physiological flexibility, here defined as their ability to respond to micro-environmental changes and modify their metabolic activity (Prosser et al., 2007). Thus, bacterial data, unless related to autotrophic organisms such as ammonia oxidizers, should be interpreted with caution. In general, the literature reports that co-inoculation of plants with AM fungi and Pseudomonas strains results in a growth stimulation for both groups of microbes. In brief, Walley and Germida (1997) demonstrated that the plant growth promoting (PGP) ability of $P$. fluorescens R92 and P. putida R104 on wheat was unaffected by inoculation with Glomus clarum NT4. Edwards et al. (1998) reported an increase in rhizosphere abundance of $P$. fluorescens following inoculation of a range of plants with G. mosseae (Nico. and Gerd.). Ravnskov and Jakobsen (1999) grew cucumber in association with P. fluorescens DF 57 and one of the AM fungi Glomus intraradices and Glomus caledonium. Along with an interactive increase in P content following co-inoculation with $G$. intraradices and P. fluorescens they reported an increase in hyphal length density of $G$. caledonium following co-inoculation with $P$. fluorescens (Ravnskov and Jakobsen, 1999). Finally, Gamalero et al. (2004) report that coinoculation with G. mosseae BEG 12 and P. fluorescens 92rk resulted in an interactive increase in growth of tomato.

\subsubsection{Mechanisms of AM fungal involvement}

Denitrification is a dissimilatory process in which, due to limiting levels of $\mathrm{O}_{2}, \mathrm{NO}_{3}^{-}$is used as an alternative terminal electron acceptor (Heylen et al., 2006). The factors other than soil aeration that could affect denitrification in soils include nitrate availability, carbon availability and quality, temperature, $\mathrm{pH}$ and soil heterogeneity (reviewed by Myrold (2005)). Proximity of denitrifiers to plant roots and plant identity could be additional factors. A multi-fold increase in denitrification rates has been reported in several instances in proximity to the root (e.g. Smith and Tiedje, 1979; Hojberg et al., 1996; Mahmood et al., 1997). Moreover, there is evidence of qualitative differences between denitrifying communities of the rhizosphere and the "bulk soil" (Chèneby et al., 2004). A decline of exuded carbon following AM colonization that is redirected to the AM mycelium may reduce the differences in denitrification rates between the rhizosphere and the "bulk" soil.

An obvious way through which AM fungi could influence denitrification rates is through modification of substrate availability (here: the terminal electron acceptor, $\mathrm{NO}_{3}^{-}$). AM fungi are believed to predominantly assimilate $\mathrm{N}$ in the form of $\mathrm{NH}_{4}^{+}$(e.g. Tanaka and Yano, 2006) and so they may not have a direct effect on $\mathrm{NO}_{3}^{-}$ availability. However, as reviewed above, there is a high likelihood that they interact with nitrification, which represents a source of soil exchangeable $\mathrm{NO}_{3}^{-}$. While AM fungi require good aeration of soil to proliferate, denitrification is an anaerobic process, characterized by high spatial variability under typical soil conditions (Parkin, 1987). AM fungi are known to form macroaggregates through a variety of mechanisms (Rillig and Mummey, 2006); thus it is likely that inside these aggregate interiors conditions conducive to denitrification prevail through the generation of anaearobic zones. Modification of carbon availability away from the root, in the hyphosphere, through hyphal exudation (Toljander et al., 2007) and the resulting shifts in the microbial community in this zone (Toljander et al., 2006) could be factors that might promote denitrification However, it is not possible to predict the exact effect of AM colonization on the denitrifying community, primarily because of the remarkable physiological flexibility of denitrifiers, mentioned above.

\subsection{N-Leaching}

\subsubsection{Evidence for AM fungal involvement}

The role of AM fungi in leaching has not been extensively studied. van der Heijden (2010) used three plant species tested at two nutrient supply rates. He was able to demonstrate significant differences in the composition of the leachate with respect to phosphate concentration for all three plants at the low nutrient supply; also with respect to $\mathrm{NH}_{4}^{+}$for Festuca ovina at the low nutrient supply and for Poa pratensis at the high nutrient supply. Given the absence of differences in the size of the plants in the experiment of van der Heijden (2010), these results signify that AM fungi may represent an effective way to limit $\mathrm{N}$-losses from an ecosystem. Asghari and Cavagnaro (2011) were, also, able to detect a decline in $\mathrm{NO}_{3}^{-}, \mathrm{NH}_{4}^{+}$, and phosphate concentrations in the leachate, which, however, could partly be attributed to the bigger size of the mycorrhizal plants. By contrast, Rillig et al. (2006b) studied leaching of DOC/DON components that may be related to AMF, but detected no measurable amounts of a putatively AMFderived protein; this study only targeted glomalin-related soil protein, and thus it cannot be used as exhaustive evidence against the occurrence of AM fungal derived $\mathrm{N}$-compounds in leachate.

\subsubsection{Mechanisms of AM fungal involvement}

Leaching is an important pathway of $\mathrm{N}$-loss especially in intensively managed ecosystems (e.g. Zhang et al., 2004). An obvious way to reduce $\mathrm{N}$-leaching would be to reduce the amount of leachate. This could occur in AM-colonized plants as a result of the improved water relations following AM colonization that include higher stomatal conductance and faster soil-drying (Augé, 2001). Moreover, improvement of soil structure in the AM mycorrhizosphere (Rillig and Mummey, 2006) and possibly water held in the hyphae could result in an increase of the water holding capacity of soil. In support of these ideas, van der Heijden (2010) detected a trend toward lower leachate volumes, in the presence of the AM community, for all six AM vs non-mycorrhizal contrasts he established. Asghari et al. (2005) also demonstrated lower leachate volumes of AM colonized plants but did not control for the bigger size of the AM treatments.

A second mechanism through which AM fungi could impact $\mathrm{N}$-leaching could be by affecting $\mathrm{NO}_{3}^{-}$concentration in the soil solution, as hypothesized in Rillig (2004). As reviewed earlier (see Sections 3.1 and 3.3), it is quite likely that AM fungi facilitate uptake of inorganic $\mathrm{N}$ and may simultaneously interact with nitrification rates. We may not know the exact effect of AM fungi on nitrification rates, however, the more efficient uptake of inorganic $\mathrm{N}$ recorded for AM plants should result in a decline in the levels of inorganic $\mathrm{N}$ in the soil solution, including $\mathrm{NO}_{3}^{-}$. We thus predict a decline in $\mathrm{N}$-losses through leaching in the AM mycorrhizosphere.

\section{Difficulties associated with experimentation with AM fungi - optimal experimentation procedures}

Given the ubiquity of AM associations in nature and their importance in plant nutrition it is striking how little we know of the way AM fungi could impact $\mathrm{N}$-cycling processes. There may be several reasons that can explain this gap in our knowledge. An important one is likely the historical focus of AM researchers on $\mathrm{P}$ nutrition, which is partially well justified owing to the higher intensity of AM interactions with $\mathrm{P}$ cycling processes. It can be safely stated, however, that our limited knowledge on AM interactions with $\mathrm{N}$-cycling organisms largely reflects the well known difficulties inherent to experimentation with AM fungi; these are compounded with specific issues regarding the $\mathrm{N}$-cycle, as discussed in the following. 
Ubiquitous occurrence of AM fungi makes it difficult to either reduce or retrieve soil without AM fungal propagules. Systemic fungicides often fail to effectively reduce AM root colonization (e.g. Pedersen and Sylvia, 1997), suppress a large segment of the soil fungal community (non-target effects), or result in indirect effects such as an increase in nutrient availability due to mineralization of fungal biomass (Milenkovski et al., 2010). Most importantly there is evidence that they may interfere with nitrification and $\mathrm{N}$-cycling processes (Martens and Bremner, 1997). The only available process to effectively remove AM fungal propagules from soil is a sterilization procedure. Sterilization and reinoculation with an extracted microbial community and/or AM fungi is a common way to overcome some of the problems introduced by soil sterilization. However, the logistics of conducting large scale ecological experimentation using that technique are daunting. On the other hand, the microbial community of the mesocosms, even following an equilibration period as suggested in some studies (e.g. Shaw et al., 1999), may not be representative of the indigenous microbial community of the original soil. While working with such re-established microbial communities (for the purposes of equilibrating microbial 'background' among treatments) may be sufficient for general experimentation, when the focus is the microbially regulated $\mathrm{N}$-cycle, it becomes absolutely critical to achieve conditions that resemble the non-sterilized soil as much as possible. A good example of a microbial group that may be difficult to work with is ammonia oxidizers. Their low duplication rates, exceeding several days under laboratory conditions (Prosser, 1989), mean that the actual equilibration time required for them to reach pre-sterilization densities may involve a waiting stage of several months. As a result, long preparatory phases may be required to allow for optimal conditions of experimentation.

A parallel major problem lies in the difficulty of segregating the root/rhizodeposition effect from the AM-mediated impact in the hyphosphere. AM fungi are obligate symbionts; this means that in experiments the combined effect of roots and hyphae are commonly measured, with the root influence likely of much greater importance. To study the AM-associated changes the most common approach is to use compartmented systems with the incorporation of fine meshes that permit access only to hyphae, excluding roots. Following such a procedure, it is often speculated that soil that has not been in the reach of the roots represents the hyphosphere. However, visualization of the hyphosphere is not possible prior to destructive harvest of the microcosms; this is in contrast to ectomycorrhizal systems where it is possible to work with non-sterilized material and to sample hyphosphere soil in the proximity of rhizomorphs (e.g. Bomberg et al., 2003). In some instances microcosms have been harvested without checking the successful establishment of the AM fungi in the hyphosphere compartment, and interpretation of results from those studies may be difficult. Even in the instances of verified presence of a dense hyphosphere, AM colonization of soil could be biased toward "runner hyphae", long, thin exploratory hyphae that form few to no branches (Friese and Allen, 1991; Smith et al., 2000). Though there have been no studies to specifically target the microbial communities supported in the different types of AM hyphae, given the potential inability of runner hyphae to absorb nutrients it is quite likely that their potential overrepresentation at sampling represents an additional source of bias.

Using soil that has a short history of colonization from terrestrial plants such as the glacial forefront plant communities may be an interesting alternative to the use of sterilized/reinoculated soil (Cázares et al., 2005). The specific ecosystems lack or contain only few AM propagules, and thus soil can be used without pretreatment to establish AM-inoculated and AM-free treatments that may be directly compared, but at the cost of potential lack of external validity beyond these soils. Another caveat may be that these areas may be colonized by plants that are not responsive to AM fungi, or by plants which do not form this association.

An exciting opportunity is working with AM-deficient mutants/ wild-type pairs (e.g. Cavagnaro et al., 2004; Facelli et al., 2010). Although a wide range of AM-deficient plant mutants is available, preliminary experimentation for indirect effects of mutants is important and simultaneous experimentation with more than one mutant desirable because the identity of plant mutant could interact with the results (e.g. Rillig et al., 2008). The clear advantage of pursuing this approach, when properly validated, is that the microbial community does not need to be modified, as the nonmycorrhizal status is created experimentally by a non-host; this represents a near-ideal condition for mechanistic studies.

While not typically permitting detailed mechanistic understanding, observational/correlational approaches represent a choice for obtaining results with a high level of ecological realism. It may be possible to use dissimilarities based analysis of interactions of microbial communities or path analysis to tease apart factors related to AM fungal abundance and its relationship with different $\mathrm{N}$-cycling process rates; this approach has already been used for the study of general microbial community relationships (Singh et al., 2008) and other AMF functions, such as soil aggregation (Barto et al., 2010). Through the use of these techniques, it is also possible to simultaneously and explicitly examine direct and indirect effects (paths).

\section{Conclusions}

We have shown that the amount of available evidence on the potential effects of AM fungi on individual $\mathrm{N}$-cycling processes varies considerably. The majority of studies on the interactive effect of $\mathrm{AM}$ and the N-cycle unsurprisingly focuses on economically/ agriculturally important aspects of the $\mathrm{N}$-cycle such as the ability of plants to assimilate $\mathrm{N}$ and symbiotic $\mathrm{N}_{2}$-fixation. Yet despite the wealth of studies that have addressed the interactive effect of AM fungi on $\mathrm{N}$-assimilation the ecological significance of the process (Smith and Smith, 2011) as well as the conditions under which the role of AM fungi may be important (Fitter et al., 2011) are still not well understood. There appears to be solid evidence that AM fungi do contribute to an increased ability of legumes to fix $\mathrm{N}_{2}$ and also to a decline in the amount of inorganic $\mathrm{N}$ that leaches. By contrast, literature available to date does not allow us to reach a definitive conclusion whether there is also an AM effect on associative nitrogen fixation, nitrification and denitrification, despite the fact that plausible mechanisms exist for these effects. Taken together, there is a high likelihood that AM fungi play a role as drivers of $\mathrm{N}$-cycling, which has not been appreciated hitherto.

Much of our knowledge on soil microbial communities associated with plants results from experimentation in the absence of mycorrhizal fungi or in systems where the plant's mycorrhizal status was not characterized. As a result, our understanding of microbial communities in the rhizosphere of plants still remains biased to the non-mycorrhizal condition (Hartmann et al., 2009). Many open questions that could guide future research remain: (i) what is the relative importance of the AM fungal influence, i.e. when should mycorrhiza be considered and when is it safe to ignore them; (ii) what is the role of diversity of AM fungi, given that there are tendencies within the phylum Glomeromycota for diverging functions (Powell et al., 2011); (iii) how can the study of $\mathrm{AM}$ impact be focused on isolated $\mathrm{N}$-cycling processes given the high interdependence of $\mathrm{N}$-cycling processes; (iv) what is the relative importance of direct AM-induced effects compared to more general AM-mediated plant and microbial community effects on $\mathrm{N}$-cycling processes. We hope to have stimulated soil microbial ecologists and mycorrhizal biologists to tackle some of these important issues. 


\section{Acknowledgments}

We are grateful to Prof. S. E. Smith for discussions and comments on the manuscript. Initial ideas for this review were discussed during a workshop "Soil microbial processes and nutrient cycling", which took place at the Chinese Academy of Sciences, Beijing, in September 2010. B.C. was supported by a fellowship by the Alexander-vonHumboldt Foundation during the writing of this paper, and S.D.V. acknowledges partial support from the Center for International Cooperation at Freie Universität Berlin.

\section{References}

Abbott, L.K., Robson, A.D., 1978. Growth of subterranean clover in relation to the formation of endomycorrhizas by introduced and indigenous fungi in a field soil. New Phytologist 81, 575-585.

Abbott, L.K., Robson, A.D., Parker, C.A., 1979. Double symbiosis in legumes - the role of mycorrhizas. In: Broughton, W.J., John, Z.K., Bajaraoj, J.C., Beda, L. (Eds.), Soil Microbiology and Plant Nutrition. Penerbit University Malaya, Kuala Lumpur, pp. 176-181.

Albertsen, A., Ravnskov, S., Green, H., Jensen, D.F., Larsen, J., 2006. Interactions between the external mycelium of the mycorrhizal fungus Glomus intraradices and other soil microorganisms as affected by organic matter. Soil Biology and Biochemistry 38, 1008-1014.

Amora-Lazcano, E., Vázquez, M.M., Azcón, R., 1998. Response of nitrogentransforming microorganisms to arbuscular mycorrhizal fungi. Biology and Fertility of Soils 27, 65-70.

Andrade, G., Linderman, R.G., Bethlenfalvay, G.J., 1998. Bacterial associations with the mycorrhizosphere and hyphosphere of the arbuscular mycorrhizal fungus Glomus mosseae. Plant and Soil 202, 79-87.

Asghari, H., Cavagnaro, T., 2011. Arbuscular mycorrhizas enhance plant interception of leached nutrients. Functional Plant Biology 38, 219-226.

Asghari, H.R., Chittleborough, D.J., Smith, F.A., Smith, S.E., 2005. Influence of arbuscular mycorrhizal (AM) symbiosis on phosphorus leaching through cores. Plant and Soil 275, 181-193.

Atul-Nayyar, A., Hamel, C., Hanson, K., Germida, J., 2009. The arbuscular mycorrhizal symbiosis links N mineralization to plant demand. Mycorrhiza 19, 239-246.

Augé, R.M., 2001. Water relations, drought and vesicular-arbuscular mycorrhizal symbiosis. Mycorrhiza 11, 3-42.

Avrahami, S., Bohannan, B.J.A., 2007. Response of Nitrosospira sp strain AF-Like ammonia oxidizers to changes in temperature, soil moisture content, and fertilizer concentration. Applied and Environmental Microbiology 73, 1166-1173.

Bago, B., Vierheilig, H., Piche, Y., Azcon-Aguilar, C., 1996. Nitrate depletion and pH changes induced by the extraradical mycelium of the arbuscular mycorrhizal fungus Glomus intraradices grown in monoxenic culture. New Phytologist 133, 273-280.

Bardgett, R.D., Bowman, D., Kaufmann, R., Schmidt, S.K., 2005. A temporal approach to linking aboveground and belowground ecology. Trends in Ecology and Evolution 20, 634-641.

Barrett, G., Campbell, C.D., Fitter, A.H., Hodge, A., 2011. The arbuscular mycorrhizal fungus Glomus hoi can capture and transfer nitrogen from organic patches to its associated host plant at low temperature. Applied Soil Ecology 48, 102-105.

Barto, E.K., Alt, F., Oelmann, Y., Wilcke, W., Rillig, M.C., 2010. Contributions of biotic and abiotic factors to soil aggregation across a land use gradient. Soil Biology and Biochemistry 42, 2316-2324.

Bashan, Y., Holguin, G., de Bashan, L.E., 2004. Azospirillum plant relationships, physiological, molecular, agricultural, and environmental advances (1997-2003). Canadian Journal of Microbiology 50, 521-577.

Bianciotto, V., Bandi, C., Minerdi, D., Sironi, M., Tichy, H.V., Bonfante, P., 1996. An obligately endosymbiotic mycorrhizal fungus itself harbors obligately intracellular bacteria. Applied and Environmental Microbiology 62, 3005-3010.

Blaha, C.A.G., Schrank, I.S., 2003. An Azospirillum brasilense Tn5 mutant with modified stress response and impaired in flocculation. Antonie Van Leeuwenhoek - International Journal of General and Molecular Microbiology 83, 35-43.

Bollmann, A., Bår-Gilissen, M.-J., Laanbroek, H.J., 2002. Growth at low ammonium concentrations and starvation response as potential factors involved in niche differentiation among ammonia-oxidizing bacteria. Applied and Environmental Microbiology 68, 4751-4757.

Bomberg, M., Jurgens, G., Saano, A., Sen, R., Timonen, S., 2003. Nested PCR detection of Archaea in defined compartments of pine mycorrhizospheres developed in boreal forest humus microcosms. FEMS Microbiology Ecology 43, 163-171.

Booth, M.S., Stark, J.M., Rastetter, E., 2005. Controls on nitrogen cycling in terrestrial ecosystems: a synthetic analysis of literature data. Ecological Monographs 75, 139-157.

Bouyoucos, G.J., 1939. Effect of organic matter on the water-holding capacity and the wilting point of mineral soils. Soil Science 47, 377-384.

Brinkman, E.P., Van der Putten, W.H., Bakker, E.J., Verhoeven, K.J.F., 2010. Plant-soil feedback: experimental approaches, statistical analyses and ecological interpretations. Journal of Ecology 98, 1063-1073.
Bucher, M., 2007. Functional biology of plant phosphate uptake at root and mycorrhiza interfaces. New Phytologist 173, 11-26.

Bunn, R., Lekberg, Y., Zabinski, C., 2009. Arbuscular mycorrhizal fungi ameliorate temperature stress in thermophilic plants. Ecology 90, 1378-1388.

Cavagnaro, T.R., Smith, F.A., Smith, S.E., 2004. Interactions between arbuscular mycorrhizal fungi and a mycorrhizal-defective mutant tomato: does a noninfective fungus alter the ability of an infective fungus to colonize the roots - and vice versa? New Phytologist 164, 485-491.

Cavagnaro, T.R., Jackson, L.E., Scow, K.M., Hristova, K.R., 2007. Effects of arbuscular mycorrhizas on ammonia oxidizing bacteria in an organic farm soil. Microbial Ecology 54, 618-626.

Cázares, E., Trappe, J.M., Jumpponen, A., 2005. Mycorrhiza-plant colonization patterns on a subalpine glacier forefront as a model system of primary succession. Mycorrhiza 15, 405-416.

Chapin III, F.S., Mooney, H.A., Chapin, M.C., Matson, P., 2004. Principles of Terrestrial Ecosystem Ecology. Springer.

Chèneby, D., Perrez, S., Devroe, C., Hallet, S., Couton, Y., Bizouard, F., Iuretig, G., Germon, J.C., Philippot, L., 2004. Denitrifying bacteria in bulk and maizerhizosphere soil: diversity and $\mathrm{N}_{2} \mathrm{O}$-reducing abilities. Canadian Journal of Microbiology 50, 469-474.

Christensen, H., Jakobsen, I., 1993. Reduction of bacterial-growth by a vesiculararbuscular mycorrhizal fungus in the rhizosphere of cucumber (Cutumis sativus L.). Biology and Fertility of Soils 15, 253-258.

Collins, C.D., Foster, B.L., 2009. Community-level consequences of mycorrhizae depend on phosphorus availability. Ecology 90, 2567-2576.

Craine, J.M., Morrow, C., Fierer, N., 2007. Microbial nitrogen limitation increases decomposition. Ecology 88, 2105-2113.

Currie, W.S., Aber, J.D., 1997. Modeling leaching as a decomposition process in humid Montane forests. Ecology 78, 1844-1860.

Davidson, E.A., Matson, P.A., Vitousek, P.M., Riley, R., Dunkin, K., Garciamendez, G., Maass, J.M., 1993. Processes regulating soil emissions of $\mathrm{NO}$ and $\mathrm{N}_{2} \mathrm{O}$ in a seasonally dry tropical forest. Ecology 74, 130-139.

De Boer, W., Kowalchuk, G.A., 2001. Nitrification in acid soils, microorganisms and mechanisms. Soil Biology and Biochemistry 33, 853-866.

de Boer, W., Folman, L.B., Summerbell, R.C., Boddy, L., 2005. Living in a fungal world: impact of fungi on soil bacterial niche development. FEMS Microbiology Reviews 29, 795-811.

de Nobili, M., Contin, M., Mondini, C., Brookes, P.C., 2001. Soil microbial biomass is triggered into activity by trace amounts of substrate. Soil Biology and Biochemistry 33, 1163-1170.

Demoling, F., Figueroa, D., Bååth, E., 2007. Comparison of factors limiting bacterial growth in different soils. Soil Biology and Biochemistry 39, 2485-2495.

Dijkstra, F.A., Hobbie, S.E., Reich, P., 2006. Soil processes affected by sixteen grassland species grown under different environmental conditions. Soil Science Society American Journal 70, 770-777.

Edwards, S.G., Young, J.P.W., Fitter, A.H., 1998. Interactions between Pseudomonas fluorescens biocontrol agents and Glomus mosseae, an arbuscular mycorrhiza fungus, within the rhizosphere. FEMS Microbiology Letters 166, 297-303.

Enoch, H., Dasberg, S., 1971. The occurrence of high $\mathrm{CO}_{2}$ concentrations in soil air. Geoderma 6, 17-21.

Facelli, E., Smith, S.E., Facelli, J.M., Christophersen, H.M., Smith, F.A., 2010. Underground friends or enemies: model plants help to unravel direct and indirect effects of arbuscular mycorrhizal fungi on plant competition. New Phytologist 185, 1050-1061.

Fitter, A.H., Stickland, T.R., Harvey, M.L., Wilson, G.W., 1991. Architectural analysis of plant-root systems. 1. Architectural correlates of exploitation efficiency. New Phytologist 118, 375-382.

Fitter, A.H., Helgason, T., Hodge, A., 2011. Nutritional exchanges in the arbuscular mycorrhizal symbiosis: implications for sustainable agriculture. Fungal Biology Reviews 25, 68-72.

Fitter, A.H., 2005. Darkness visible: reflections on underground ecology. Journal of Ecology 93, 231-243.

Frank, D.A., Groffman, P.M., 2009. Plant rhizospheric N processes: what we don't know and why we should care. Ecology 90, 1512-1519.

Friese, C.F., Allen, M.F., 1991. The spread of VA mycorrhizal fungal hyphae in the soil: inoculum types and external hyphal structure. Mycologia 83, 409-418.

Gamalero, E., Trotta, A., Massa, N., Copetta, A., Martinotti, M.G., Berta, G., 2004. Impact of two fluorescent pseudomonads and an arbuscular mycorrhizal fungus on tomato plant growth, root architecture and P acquisition. Mycorrhiza 14, 185-192.

Garg, N., Manchanda, G., 2008. Effect of arbuscular mycorrhizal inoculation on saltinduced nodule senescence in Cajanus cajan (pigeonpea). Journal of Plant Growth Regulation 27, 115-124.

Garrido, E., Bennett, A.E., Fornoni, J., Strauss, S.Y., 2010. Variation in arbuscular mycorrhizal fungi colonization modifies the expression of tolerance to aboveground defoliation. Journal of Ecology 98, 43-49.

Gill, R.S., Jackson, R.B., 2000. Global patterns of root turnover for terrestrial ecosystems. New Phytologist 147, 13-31.

Govindarajulu, M., Pfeffer, P.E., Jin, H.R., Abubaker, J., Douds, D.D., Allen, J.W., Bucking, H., Lammers, P.J., Shachar-Hill, Y., 2005. Nitrogen transfer in the arbuscular mycorrhizal symbiosis. Nature 435, 819-823.

Griffiths, B.S., Ritz, K., Wheatley, R., Kuan, H.L., Boag, B., Christensen, S., Ekelund, F. Sorensen, S.J., Muller, S., Bloem, J., 2001. An examination of the biodiversityecosystem function relationship in arable soil microbial communities. Soil Biology and Biochemistry 33, 1713-1722. 
Harris, J., 2009. Soil microbial communities and restoration ecology: facilitators or followers? Science 325, 573-574.

Harrison, K.A., Bol, R., Bardgett, R.D., 2007. Preferences for different nitrogen forms by coexisting plant species and microbes. Ecology 88, 989-999.

Hartmann, A., Schmid, M., van Tuinen, D., Berg, G., 2009. Plant-driven selection of microbes. Plant and Soil 321, 235-257.

Helgason, T., Fitter, A.H., 2009. Natural selection and the evolutionary ecology of the arbuscular mycorrhizal fungi (Phylum Glomeromycota). Journal of Experimental Botany 60, 2465-2480.

Heylen, K., Gevers, D., Vanparys, B., Wittebolle, L., Geets, J., Boon, N., De Vos, P. 2006. The incidence of nirS and nirK and their genetic heterogeneity in cultivated denitrifiers. Environmental Microbiology 8, 2012-2021.

Hodge, A., Fitter, A.H., 2010. Substantial nitrogen acquisition by arbuscular mycorrhizal fungi from organic material has implications for $\mathrm{N}$ cycling. Proceedings of the National Academy of Sciences of the United States of America 107, 13754-13759.

Hodge, A., Campbell, C.D., Fitter, A.H., 2001. An arbuscular mycorrhizal fungus accelerates decomposition and acquires nitrogen directly from organic material. Nature 413, 297-299.

Hodge, A., Helgason, T., Fitter, A.H., 2010. Nutritional ecology of arbuscular mycorrhizal fungi. Fungal Ecology 3, 267-273.

Hoeksema, J.D., Chaudhary, V.B., Gehring, C.A., Johnson, N.C., Karst, J., Koide, R.D., Pringle, A., Zabinski, C., Bever, J.D., Moore, J.C., Wilson, G.W.T., Klironomos, J.N., Umbanhowar, J., 2010. A meta-analysis of context dependency in plant response to inoculations with mycorrhizal fungi. Ecology Letters 13, 394-407.

Hojberg, O., Binnerup, S.J., Sorensen, J., 1996. Potential rates of ammonium oxidation, nitrite oxidation, nitrate reduction and denitrification in the young barley rhizosphere. Soil Biology and Biochemistry 28, 47-54.

Hooker, J.E., Munro, M., Atkinson, D., 1992. Vesicular-arbuscular mycorrhizal fungi induced alteration in poplar root system morphology. Plant and Soil 145 207-214

Hooker, J.E., Piatti, P., Cheshire, M.V., Watson, C.S., 2007. Polysaccharides and monosaccharides in the hyphosphere of the arbuscular mycorrhizal fung Glomus E3 and Glomus tenue. Soil Biology and Biochemistry 39, 680-683.

Ibijbijen, J., Urquiaga, S., Ismaili, M., Alves, B.J.R., Boddey, R.M., 1996. Effect of arbuscular mycorrhizal fungi on growth, mineral nutrition and nitrogen fixation of three varieties of common beans (Phaseolus vulgaris). New Phytologist $134,353-360$

Jackson, R.B., Canadell, J., Ehleringer, J.R., Mooney, H.A., Sala, O.E., Schulze, E.D., 1996 A global analysis of root distributions for terrestrial biomes. Oecologia 108 389-411.

Jansa, J., Smith, F.A., Smith, S.E., 2008. Are there benefits of simultaneous root colonization by different arbuscular mycorrhizal fungi? New Phytologist 177, 779-789.

Javot, H., Pumplin, N., Harison, M.,. 2007. Phosphate in the arbuscular mycorrhiza symbiosis: transporter properties and regulatory roles. Plant Cell and Environment 30, 310-322.

Jha, D.K., Sharma, G.D., Mishra, R.R., 1993. Mineral nutrition in the tripartine interaction between Frankia, Glomus and Alnus at different soil-phosphorus regimes. New Phytologist 123, 307-311.

Jin, H., Pfeffer, P.E., Douds, D.D., Piotrowski, E., Lammers, P.J., Shachar-Hill, Y., 2005 The uptake, metabolism, transport and transfer of nitrogen in an arbuscular mycorrhizal symbiosis. New Phytologist 168, 687-696.

Johansen, A., Jakobsen, I., Jensen, E.S., 1992. Hyphal transport of ${ }^{15} \mathrm{~N}$-labelled nitrogen by a vesicular-arbuscular mycorrhizal fungus and its effect on depletion of inorganic soil N. New Phytologist 122, 281-288.

Jones, D.L., Hodge, A., Kuzyakov, Y., 2004. Plant and mycorrhizal regulation of rhizodeposition. New Phytologist 163, 459-480.

Kaschuk, G., Leffelaar, P.A., Giller, K.E., Alberton, O., Hungria, M., Kuyper, T.W., 2010. Responses of legumes to rhizobia and arbuscular mycorrhizal fungi: a metaanalysis of potential photosynthate limitation of symbioses. Soil Biology and Biochemistry 42, 125-127.

Kiers, E.T., Duhamel, M., Beesetty, Y., Mensah, J.A., Franken, O., Verbruggen, E Fellbaum, C.R., Kowalchuk, G.A., Hart, M.M., Bago, A., Palmer, T.M., West, S.A Vandenkoornhuyse, P., Jansa, J., Bücking, H., 2011. Reciprocal rewards stabilize cooperation in the mycorrhizal symbiosis. Science 333, 880-882.

Kim, M., Jeong, S.-Y., Yoon, S.J., Cho, S.J., Kim, Y.H., Kim, M.J., Ryu, E.Y., Lee, S.-J., 2008. Aerobic denitrification of Pseudomonas putida AD-21 at different $\mathrm{C} / \mathrm{N}$ ratios. Journal of Bioscience and Bioengineering 106, 498-502.

Kneip, C., Lockhart, P., Voss, C., Maier, U.G., 2007. Nitrogen fixation in eukaryotes New models for symbiosis. BMC Evolutionary Biology 7, 55.

Koricheva, J., Gange, A.C., Jones, T., 2009. Effects of mycorrhizal fungi on insect herbivores: a meta-analysis. Ecology 90, 2088-2097.

Lambers, H., Raven, J.A., Shaver, G.R., Smith, S.E., 2008. Plant nutrient-acquisition strategies change with soil age. Trends in Ecology and Evolution 23, 95-103.

Landis, F.C., Gargas, A., Givnish, T.J., 2005. The influence of arbuscular mycorrhizae and light on Wisconsin (USA) sand savanna understories. 1-Plant community composition. Mycorrhiza 15, 547-553.

Larimer, A.L., Bever, J.D., Clay, K., 2010. The interactive effects of plant microbia symbionts: a review and meta-analysis. Symbiosis 51, 139-148.

Leigh, J., Hodge, A., Fitter, A.H., 2009. Arbuscular mycorrhizal fungi can transfer substantial amounts of nitrogen to their host plant from organic material. New Phytologist 181, 199-207.

Leigh, J., Fitter, A.H., Hodge, A., 2011. Growth and symbiotic effectiveness of an arbuscular mycorrhizal fungus in organic matter in competition with soil bacteria. FEMS Microbiology Ecology 76, 428-438.
Lekberg, Y., Koide, R.T., 2005. Is plant performance limited by abundance of arbuscular mycorrhizal fungi? A meta-analysis of studies published between 1988 and 2003. New Phytologist 168, 189-204.

Li, X.L., George, E., Marschner, H., 1991. Phosphorus depletion and pH decrease at the root soil and hyphae soil interfaces of VA mycorrhizal white clover fertilized with ammonium. New Phytologist 119, 379-404.

Liebich, J., Schloter, M., Schäffer, A., Vereecken, H., Burauel, P., 2007. Degradation and humification of maize straw in soil microcosms inoculated with simple and complex microbial communities. European Journal of Soil Science 58, 141-151.

Ma, B.L., Dwyer, L.M., Gregorich, E.G., 1999. Soil nitrogen amendment effects on seasonal nitrogen mineralization and nitrogen cycling in maize production. Agronomy Journal 91, 1003-1009.

Mahmood, T., Ali, R., Malik, K.A., Shamsi, S.R.A., 1997. Denitrification with and without maize plants (Zea mays L.) under irrigated field conditions. Biology and Fertility of Soils 24, 323-328.

Marschner, P., Baumann, K., 2003. Changes in bacterial community structure, induces by mycorrhizal colonization in split-root maize. Plant and Soil 251, 279-289.

Marschner, P., Crowley, D.E., Lieberei, R., 2001. Arbuscular mycorrhizal infection changes the bacterial 16S rDNA community composition in the rhizosphere of maize. Mycorrhiza 11, 297-302.

Marschner, H., 1995. Mineral Nutrition of Higher Plants. Academic Press, London.

Martens, D.A., Bremner, J.M., 1997. Inhibitory effects of fungicides on hydrolysis of urea and nitrification of urea nitrogen in soil. Pesticide Science 49, 344-352.

Mazzola, M., 2004. Assessment and management of soil microbial community structure for disease suppression. Annual Review in Phytopathology 42, 35-59.

Milenkovski, S., Baath, E., Lindgren, P.E., Berglund, O., 2010. Toxicity of fungicides to natural bacterial communities in wetland water and sediment measured using leucine incorporation and potential denitrification. Ecotoxicology 19, 285-294.

Miller, R.M. Jastrow, J.D. 2002. Mycorrhizal influence on soil structure. In: Kapulnik, Y., Douds, D.D. (Eds.), Arbuscular Mycorrhizae: Molecular Biology and Physiology. Kluwer Academic Publishers, Dordrecht, The Netherlands, pp. 3-18.

Minerdi, D., Fani, R., Gallo, R., Boarino, A., Bonfante, P., 2001. Nitrogen fixation genes in an endosymbiotic Burkholderia strain. Applied and Environmental Microbiology 67, 725-732.

Moorhead, D.L., Sinsabaugh, R.L., 2006. A theoretical model of litter decay and microbial interaction. Ecological Monographs 76, 151-174.

Mrkovački, N., Milić, V., 2001. Use of Azotobacter chroococcum as potentially useful in agricultural application. Annals of Microbiology 51, 145-158.

Myrold, D.D., 2005. Transformations of nitrogen. In: Sylvia, D.M., Hartel, P.G., Fuhrmann, J.J., Zuberer, D.A. (Eds.), Principles and Applications of Soil Microbiology. Pearson Education Inc, New Jersey.

Nannipieri, P., Ascher, J., Ceccherini, M.T., Landi, L., Pietramellara, G., Renella, G., 2003. Microbial diversity and soil functions. European Journal of Soil Science 54, 655-670.

Newsham, K.K., Fitter, A.H., Watkinson, A.R., 1995. Multi-functionality and biodiversity in arbuscular mycorrhizas. Trends in Ecology and Evolution 10, 407-411.

Oliveira, R.S., Castro, P.M.L., Dodd, J.C., Vosatka, M., 2005. Synergistic effect of Glomus intraradices and Frankia spp. on the growth and stress recovery of Alnus glutinosa in an alkaline anthropogenic sediment. Chemosphere 60, 1462-1470.

Olsson, M.O., Falgengren-Grerup, U., 2000. Potential nitrification as an indicator of preferential uptake of ammonium or nitrate by plants in an oak woodland understorey. Annals of Botany 85, 299-305.

Olsson, P.A., Johnson, N.C., 2005. Tracking carbon from the atmosphere to the rhizosphere. Ecology Letters 8, 1264-1270.

Parkin, T.B., 1987. Soil microsites as a source of denitrification variability. Soil Science Society of America Journal 51, 1194-1199.

Paul, E.A., Kucey, R.M.N., 1981. Carbon flow in plant microbial associations. Science 213, 473-474.

Pedersen, C.T., Sylvia, D.M., 1997. Limitations to using benomyl in evaluating mycorrhizal functioning. Biology and Fertility of Soils 25, 163-168.

Powell, J.R., Monaghan, M.T., Öpik, M., Rillig, M.C., 2011. Evolutionary criteria outperform operational approaches in producing ecologically-relevant fungal species inventories. Molecular Ecology 20, 655-666.

Prosser, J.I., Bohannan, B.J.M., Curtis, T.P., Ellis, R.J., Firestone, M.K., Freckleton, R.P. Green, J.L., Green, L.E., Killham, K., Lemmon, J.J., Osborn, A.M., Solan, M., van der Gast, C.J., Young, P.W., 2007. The role of ecological theory in microbial ecology. Nature Reviews Microbiology 5, 384-392.

Prosser, J.I. 1989. Autotrophic nitrification in bacteria. Advances in Microbial Physiology 30, 125-189.

Puppi, G., Azcón, R., Höflich, G., 1994. Management of positive interactions of arbuscular mycorrhizal fungi with essential groups of soil microorganisms. In: Gianinazzi, S., Schüepp, H. (Eds.), Impact of Arbuscular Mycorrhizas on Sustainable Agriculture and Natural Ecosystems. Birkhäuser, Vergal, Basel, Switzerland, pp. 201-215.

Raven, J.A., Wollenweber, B., Handley, L.L., 1992. A comparison of ammonium and nitrate as nitrogen sources for photolithotrophs. New Phytologist 121, 19-35.

Ravnskov, S., Jakobsen, I., 1999. Effects of Pseudomonas fluorescens DF57 on growth and $\mathrm{P}$ uptake of two arbuscular fungi in symbiosis with cucumber. Mycorrhiza 8, 329-334

Read, D.J., Perez-Moreno, J., 2003. Mycorrhizas and nutrient cycling in ecosystems a journey towards relevance? New Phytologist 157, 475-492.

Rengel, Z., 2002. Breeding for better symbiosis. Plant and Soil 245, 147-162.

Reynolds, H.L., Hartley, A.E., Vogelsang, K.M., Bever, J.D., Schultz, P.A., 2005. Arbuscular mycorrhizal fungi do not enhance nitrogen acquisition and growth 
of old-field perennials under low nitrogen supply in glasshouse culture. New Phytologist 167, 869-880.

Rillig, M.C., Mummey, D.L., 2006. Mycorrhizas and soil structure. New Phytologist $171,41-53$.

Rillig, M.C., Mummey, D.L., Ramsey, P.W., Klironomos, J.N., Gannon, J.E., 2006a. Phylogeny of arbuscular mycorrhizal fungi predicts community composition of symbiosis-associated bacteria. FEMS Microbiology Ecology 57, 389-395.

Rillig, M.C., Hoye, A.T., Carran, A., 2006b. Minimal direct contribution of arbuscular mycorrhizal fungi to DOC leaching in grassland through losses of glomalinrelated soil protein. Soil Biology and Biochemistry 38, 2967-2970.

Rillig, M.C., Ramsey, P.W., Gannon, J.E., Mummey, D.L., Gadkar, V., Kapulnik, Y., 2008. Suitability of mycorrhiza-defective mutant/wildtype plant pairs (Solanum lycopersicum L. cv Micro-Tom) to address questions in mycorrhizal soil ecology. Plant and Soil 308, 267-275.

Rillig, M.C., 2004. Arbuscular mycorrhizae and terrestrial ecosystem processes. Ecology Letters 7, 740-754.

Samuelsson, M.-O., Cadez, P., Gustafsson, L., 1998. Heat production by the denitrifying bacterium Pseudomonas fluorescens and the dissimilatory ammoniumproducing bacterium Pseudomonas putrefaciens during anaerobic growth with nitrate as the electron acceptor. Applied and Environmental Microbiology 54, 2220-2225.

Scheublin, T.R., van der Heijden, M.G.A., 2006. Arbuscular mycorrhizal fungi colonize nonfixing root nodules of several legume species. New Phytologist 172, $732-738$.

Scheublin, T.R., Ridgway, K.P., Young, J.P.W., van der Heijden, M.G.A., 2004. Nonlegumes, legumes, and root nodules harbor different arbuscular mycorrhizal fungal communities. Applied and Environmental Microbiology 70, 6240-6246.

Schüßler, A., Schwarzott, D., Walker, C., 2001. A new fungal phylum, the Glomeromycota: phylogeny and evolution. Mycological Research 105, 1413-1421.

Shah, M.A., Reshi, Z., Rashid, I., 2008. Mycorrhizal source and neighbour identity differently influence Anthemis cotula L. invasion in the Kashmir Himalaya, India. Applied Soil Ecology 40, 330-337.

Sharma, H., Kumar, V., Behl, R.K., Narula, N., 2002. Survival of Azotobacter chroococcum in the rhizosphere of three different wheat crosses, effect of AM fungi. Plant Nutrition 92, 634-635.

Shaw, L.J., Beaton, Y., Glover, L.A., Killham, K., Meharg, A.A., 1999. Re-inoculation of autoclaved soil as a non-sterile treatment for xenobiotic sorption and biodegradation studies. Applied Soil Ecology 11, 217-226.

Sikes, B.A., Powell, J.R., Rillig, M.C., 2010. Deciphering the relative contributions of multiple functions within plant - microbe symbiosis. Ecology 91, 1591-1597.

Singh, B.K., Nunan, N., Ridgway, K.P., McNicol, J., Young, J.P.W., Daniell, T.J., Prosser, J.I., Millard, P., 2008. Relationship between assemblages of mycorrhizal fungi and bacteria on grass roots. Environmental Microbiology 10, 534-541.

Smith, S.E., Daft, M.J., 1977. Interactions between growth, phosphate content and $\mathrm{N}_{2}$ fixation in mycorrhizal and non-mycorrhizal Medicago sativa. Australian Journal of Plant Physiology 4, 403-413.

Smith, S.E., Read, D.J., 2008. Mycorrhizal Symbiosis. Academic Press, Cambridge.

Smith, S.E., Smith, F.A., 2011. Roles of arbuscular mycorrhizas in plant nutrition and growth: new paradigms from cellular to ecosystem scales. Annual Review of Plant Biology 62, 227-250.

Smith, M.S., Tiedje, J.M., 1979. Phases of denitrification following oxygen depletion in soil. Soil Biology and Biochemistry 11, 261-267.

Smith, F.A., Jakobsen, I., Smith, S.E., 2000. Spatial differences in acquisition of soil phosphate between two arbuscular mycorrhizal fungi in symbiosis with Medicago trunculata. New Phytologist 147, 357-366.

Stacey, G., 2007. The Rhizobium - legume nitrogen fixing symbiosis. In: Bothe, H., Ferguson, S.J., Newton, W.E. (Eds.), Biology of the Nitrogen Cycle. Elsevier, London.

Staddon, P.L., Ramsey, C.B., Ostle, N., Oneson, P., Fitter, A.H., 2003. Rapid turnover of hyphae of mycorrhizal fungi determined by AMS microanalysis of C-14. Science 300, 1138-1140.

Tanaka, Y., Yano, K., 2006. Nitrogen delivery to maize via mycorrhizal hyphae depends on the form of N supplied. Plant, Cell and Environment 28, 1247-1254.

Temple, S.J., Vance, C.P., Cantt, J.S., 1998. Glutamate synthetase and nitrogen assimilation. Trends in Plant Science 3, 51-56.

Tian, C., Kasiborski, B., Koul, R., Lammers, P.J., Bücking, H., Yair, S.-H., 2010. Regulation of the nitrogen transfer pathway in the arbuscular mycorrhizal symbiosis: gene characterization and the coordination of expression with nitrogen flux. Plant Physiology 153, 1175-1187.

Tiedje, J.M., Asuming-Brempong, S., Nüsslein, K., Marsh, T.L., Flynn, S.J., 1999. Opening the black box of soil microbial diversity. Applied Soil Ecology 13, $109-122$.

Tisdall, J.M., Oades, J.M., 1982. Organic matter and water-stable aggregates in soils. Journal of Soil Science 33, 141-163.

Toljander, J.F., Artursson, V., Paul, L.R., Jansson, J.K., Finlay, R.D., 2006. Attachment of different soil bacteria to arbuscular mycorrhizal fungal extraradical hyphae is determined by hyphal vitality and fungal species. FEMS Microbiology Letters 254, 34-40.
Toljander, J.F., Lindahl, B.D., Paul, L.R., Elfstrand, M., Finlay, R.D., 2007. Influence of arbuscular mycorrhizal mycelial exudates on soil bacterial growth and community structure. FEMS Microbiology Ecology 61, 295-304.

Toro, M., Azcón, R., Barea, J.M., 1997. Improvement of arbuscular mycorrhiza development by inoculation of soil with phosphate-solubilizing rhizobacteria to improve rock phosphate bioavailability $\left({ }^{32} \mathrm{P}\right)$ and nutrient cycling. Applied and Environmental Microbiology 63, 4408-4412.

Toro, M., Azcon, R., Barea, J.M., 1998. The use of isotopic dilution techniques to evaluate the interactive effects of Rhizobium genotype, mycorrhizal fungi, phosphate-solubilizing rhizobacteria and rock phosphate on nitrogen and phosphorus acquisition by Medicago sativa. New Phytologist 138, 265-273.

Uren, N.C., 2000. Types, amounts, and possible functions of compounds released into the rhizosphere by soil-grown plants. In: Pinton, R., Varanini, Z., Nannipieri, P. (Eds.), The Rhizosphere: Biochemistry and Organic Substances at the Soil-Plant Interface. Marcel Dekker, Inc, New York, pp. 19-40.

van der Heijden, M.G.A., Boller, T., Wiemken, A., Sanders, I.R., 1998. Different arbuscular mycorrhizal fungal species are potential determinants of plant community structure. Ecology 79, 2082-2091.

van der Heijden, M.G.A., Bardgett, R.D., van Straalen, N.M., 2008. The unseen majority: soil microbes as drivers of plant diversity and productivity in terrestrial ecosystems. Ecology Letters 11, 296-310.

van der Heijden, M.G.A., 2010. Mycorrhizal fungi reduce nutrient loss from model grassland ecosystems. Ecology 91, 1163-1171.

Van der Krift, T.A.J., Berendse, F., 2001. The effect of plant species on soil nitrogen mineralization. Journal of Ecology 89, 555-561.

Vázquez, M.M., César, S., Azcón, R., Barea, J.M., 2000. Interactions between arbuscular mycorrhizal fungi and other microbial inoculants (Azospirillum, Pseudomonas, Trichoderma) and their effects on microbial population and enzyme activities in the rhizosphere of maize plants. Applied Soil Ecology 15, 261-272.

Veresoglou, S.D., Menexes, G., Rillig, M.C., 2011a. Do arbuscular mycorrhizal fungi affect their allometric partition of host plant biomass to shoots and roots? A meta-analysis of studies from 1990-2010. Mycorrhiza 2011. doi:10.1007/ s00572-011-0398-7.

Veresoglou, S.D., Mamolos, A.P., Sen, R., Veresoglou, D.S., 2011b. Plant mycotrophy modulates repression of ammonia oxidizing activity in nitrogen limited, Mediterranean, grassland soils. Journal of Ecology 99, 1339-1349.

Veresoglou, S.D., Shaw, L.J., Sen, R., 2011c. Glomus intraradices and Gigaspora margarita arbuscular mycorrhizal associations differentially affect nitrogen and potassium nutrition of Plantago lanceolata in a low fertility dune soil. Plant and Soil 340, 481-490.

Vitousek, P.M., 2004. Nutrient Cycling and Limitation - Hawaii as a Model Ecosystem. Princeton University Press, Oxford and Princeton.

Volpin, H., Kapulnik, Y., 1994. Interactions of Azospirillum with beneficial soil microorganisms. In: Okon, Y. (Ed.), Azospirillum/Plant Associations. CRC Press, Boca Raton, pp. 111-118.

Wall, D.H., Fitter, A.H., Paul, E.A., 2005. Developing new perspectives from advances in soil biodiversity research. In: Bardgett, R.D., Usher, M.B., Hopkins, D.W. (Eds.), Biological Diversity and Function in Soils. Cambridge University Press, Cambridge, pp. 3-27.

Walley, F.L., Germida, J.J., 1997. Response of spring wheat (Triticum aestivum) to interactions between Pseudomonas species and Glomus clarum NT 4. Biology and Fertility of Soils 24, 365-371.

Wang, B., Qui, Y.L., 2006. Phylogenetic distribution and evolution of mycorrhizas in land plants. Mycorrhiza 16, 299-363.

Wardle, D.A., Bardgett, R.D., Klironomos, J.N., Setälä, H., van der Putten, W.H., Wall, D.H., 2004. Ecological linkages between aboveground and belowground biota. Science 304, 1629-1633.

Welsch, A.K., Burke, D.J., Hamerlynck, E.P., Hahn, D., 2010. Seasonal analysis of arbuscular mycorrhizae, nitrogen-fixing bacteria and growth performance of the salt march grass Spartina patens. Plant and Soil 330, 251-266.

Wilson, G.W.T., Harnett, D.C., 1997. Effects of mycorrhizae on plant growth and dynamics in experimental tallgrass prairie microcosms. American Journal of Botany $84,478-482$.

Wilson, G.W.T., Harnett, D.C., 1998. Interspecific variation in plant responses to mycorrhizal colonization in tallgrass prairie. American Journal of Botany 85, 1732-1738.

Wolfe, B.E., Weishampel, P.A., Klironomos, J.N., 2006. Arbuscular mycorrhizal fungi and water table affect wetland plant community composition. Journal of Ecology 94, 905-914.

Yamanaka, T., Akama, A., Li, C.Y., Okabe, H., 2005. Growth, nitrogen fixation and mineral acquisition of Alnus sieboldiana after inoculation of Frankia together with Gigaspora margarita and Pseudomonas putida. Journal of Forest Research 10, 21-26.

Yao, Q., Wang, L.R., Zhu, H.H., Chen, J.Z., 2009. Effect of arbuscular mycorrhizal fungal inoculation on root system architecture of trifoliate orange (Poncirus trifoliata L. Raf.) seedlings. Scientia Horticulturae 121, 458-461.

Zhang, T.Q., MacKenzie, A.F., Liang, B.C., 2004. Nitrate leaching from residual fertilizer $\mathrm{N}$ after spring thaw in two corn agro-ecosystems. Canadian Journal of Soil Science 84, 477-480. 